\title{
The syntactic and discursive status of c'est comme ça que (this is how) in spoken and written French
}

\author{
Frédéric Sabio and Marie-Noëlle Roubaud \\ Aix-Marseille Univ, CNRS, LPL
}

\begin{abstract}
Several recent studies devoted to French clefts involving a pronominal/adverbial morpheme such as pour ça (for that), là (there), ainsi (like this), alors (then) and comme ça (like this) demonstrate that these are likely to behave in two distinct ways, one of them being somewhat "non-prototypical" in comparison with the most commonly described narrow focus clefts. The subject of our article is to deepen the examination of the specific c'est comme ça que sequences (lit: it is like this that, "this is how"), since they have not yet received detailed attention as to their use in modern French. The 8.600.000 word corpus which was used indicates that such forms are considerably more frequent in spoken than in written data. After recalling some of the major syntactic characteristics of clefts, we will suggest that two distinct types of c'est comme ça que sequences must be identified: the first type corresponds to the most prototypical clefts endowed with a "contrastive" effect related to the expression of manner; the second type, which will be described in greater detail, cannot be viewed as a cleft but rather as a specific discourse connector, which speakers mostly use in narrative texts, in order to introduce a consequence of the set of facts previously mentioned.
\end{abstract}

\section{INTRODUCTION}

Our paper aims at investigating the c'est comme ça/cela que construction (lit: it is like this that, "this is how"), in a 8.600.000 word corpus. After recalling some of the major syntactic characteristics of clefts, we will suggest that two distinct types can be identified: the first type corresponds to the most prototypical narrow focus clefts endowed with a "contrastive" effect, whereas the second type, which will be described in greater detail, cannot be viewed as a cleft but rather as a specific discourse connector.

\section{GENERAL PRESENTATION}

\subsection{Topic of the study}

Several recent studies (Blanche-Benveniste 2006, Scappini 2013, Sabio \& Benzitoun 2013, Roubaud \& Sabio 2015, Lahousse \& Lamiroy 2017) suggest that clefts involving a pronominal/adverbial morpheme such as pour ça/cela (for that), là (there), ainsi (like this), alors (then) and comme ça/cela (like this) are likely to behave in two distinct ways, one of which appearing to be "non-prototypical" in comparison with the syntactic and discursive structure of more ordinary clefts. Just to give a broad indication of the frequency of such forms in contemporary French, a preliminary 4 million-word corpus (made up of approximately 2 million spoken words and 2 million written words) reveals the proportions in Table 1 . 


\begin{tabular}{|c|c|c|c|l|}
\cline { 2 - 5 } \multicolumn{1}{c|}{} & TOTAL & SPOKEN & WRITTEN & \multicolumn{1}{|c|}{ Ex $^{1}$} \\
\hline $\begin{array}{c}\text { c'est pourça /cela que } \\
\text { (lit: it is for this that) }\end{array}$ & $\mathbf{2 1 3}$ & $\begin{array}{c}169 \\
(79 \%)\end{array}$ & $\begin{array}{c}44 \\
(21 \%)\end{array}$ & $\begin{array}{l}\text { c'est pour ça qu'on est souvent inquiets } \\
\text { lit : it is for this that we are often worried }\end{array}$ \\
\hline $\begin{array}{c}\text { c'est là que } \\
\text { (lit: it is there that) }\end{array}$ & $\mathbf{1 7 3}$ & $\begin{array}{c}125 \\
(72 \%)\end{array}$ & $\begin{array}{c}48 \\
(28 \%)\end{array}$ & $\begin{array}{l}\text { c'est là que tout commence } \\
\text { lit : it is there that everything begins }\end{array}$ \\
\hline $\begin{array}{c}\text { c'est ainsi que } \\
\text { (lit: it is like this that) }\end{array}$ & $\mathbf{8 8}$ & $\begin{array}{c}8 \\
(9 \%)\end{array}$ & $\begin{array}{c}80 \\
(91 \%)\end{array}$ & $\begin{array}{l}\text { c'est ainsi qu'on faisait autrefois } \\
\text { lit : it is like this that we used to do }\end{array}$ \\
\hline $\begin{array}{c}\text { c'est alors que } \\
\text { (lit: it is then that) }\end{array}$ & $\mathbf{6 8}$ & $\begin{array}{c}1 \\
(2 \%)\end{array}$ & $\begin{array}{l}\text { C'est alors que resurgit l'affaire Letelier. } \\
(98 \%)\end{array}$ & $\begin{array}{l}\text { lit : It is then that the Letelier case } \\
\text { resurfaced. }\end{array}$ \\
\hline $\begin{array}{c}\text { c'est comme ça / cela que } \\
\text { (lit: it is like this that) }\end{array}$ & $\mathbf{5 4}$ & $\begin{array}{c}41 \\
(76 \%)\end{array}$ & $\begin{array}{c}13 \\
(24 \%)\end{array}$ & $\begin{array}{l}\text { c'est comme ça que je vois les choses } \\
\text { lit : it is like this that I see things }\end{array}$ \\
\hline
\end{tabular}

Table 1. Distribution of some clefts involving a pronominal/adverbial element, in a 4 million word corpus

Several of these morphemes, such as ainsi (Lahousse \& Lamiroy 2017) and là (Roubaud \& Sabio 2015) have already been investigated in detail. In this article, we wish to broaden our knowledge of the general phenomenon by considering the specific case of c'est comme ça/cela que (lit: it is like this that, "this is how"), which has not yet received detailed attention as to its use in modern French.

Let us note that among the various forms listed in table 1, comme ça/cela is the least frequent, amounting to a total of 54 occurrences.

Regarding the distribution of c'est ainsi que and c'est comme ça/cela que, which are both prototypically related to the expression of manner, a clear-cut distinction exists along the spoken versus written dimension, the former being most frequent in written data, whereas the latter is essentially found in spoken corpora. As a consequence, our study will mostly deal with spoken productions.

Finally, let us note that the 13 written occurrences are distributed equally between $c$ 'est comme ça que (7 occ.) and c'est comme cela que (6 occ.). By contrast, c'est comme cela que is not found in the spoken data, which confirms that the latter is mostly used in writing, as a "stylish" version of the more common pronoun ça.

\subsection{Data}

Our survey was based on a corpus of 8.600 .000 words, with a balanced proportion of written and oral material ${ }^{2}$. The corpus is made up of widely different genres, ranging (as far as spoken corpora are concerned) from spontaneous interactions to more formal narrative productions.

Our study, which is based on an exhaustive account of c'est comme ça que and c'est comme cela que, also takes into account the formal variations related to the verb tense (eg. c'est 'it is' versus c'était 'it was'), as well as the various morphemes that can

\footnotetext{
${ }^{1}$ Examples from Scappini (2006).

2 The spoken data consists of 4.256 .000 words, originating from 2 sub-corpora: the Orfeo database (3.250.000 words), and a subpart of the Aix-en-Provence corpus, referred to as "Corpaix" (1.006.000 words). The Orfeo database (Debaisieux dir.) is itself a combination of various spoken corpora: Valibel, Coral-rom, CLAPI, Tcof, CRFP, CFPP and a few others. The written data consists of 4.344 .000 words drawn from the CERF database (J. Véronis, Aix Marseille Univ.).
} 
occasionally be found between c'est and que, such as c'est pas comme ça que (it is not like this that), c'est tout à fait comme ça que (it is exactly like this that)...

The occurrences of c'est comme ça and c'est comme cela are distributed as shown in Table 2.

\begin{tabular}{|c|c|c|c|c|c|c|}
\hline & \multicolumn{2}{|c|}{ TOTAL } & \multicolumn{2}{|c|}{ SPOKEN } & \multicolumn{2}{|c|}{ WRITTEN } \\
\hline c'est comme ça que & 176 & \multirow{2}{*}{188} & 160 & \multirow{2}{*}{$160(85 \%)$} & 16 & \multirow{2}{*}{$28(15 \%)$} \\
\hline c'est comme cela que & 12 & & 0 & & 12 & \\
\hline
\end{tabular}

Table 2. Spoken / written occurrences of c'est comme ça/ cela que in a 8.600 .000 word corpus

The figures in Table 2 confirm that c'est comme ça/cela sequences are far more frequent in spoken data ( 85 versus $15 \%$ ). Nevertheless, one should resist the urge to consider that the spoken versus written dimension is sufficient to account for the distribution of our structures: it is a well-known fact that the distribution of grammatical forms is widely influenced by the text types and the speech style of individual speakers (Biber and Conrad, 2009). As an example, in two of the various spoken sub-corpora which we investigated (Fleuron and CLAPI, amounting to 84.812 words) not a single occurrence of our structure was found. A further study of the interaction between texts genres and linguistic structure is thus needed. A few indications will be provided in section 4 below.

\section{DESCRIPTIVE FRAMEWORK}

\subsection{Cleft constructions as a specific "utterance-type"}

This section gives a brief account of the way in which cleft constructions have been studied within the descriptive framework of the pronominal approach, in which our analysis is situated (Blanche-Benveniste et al. 1984 \& 1990, Deulofeu 1991, Van den Eynde \& Mertens 2003). Let us first point out that, from the 1980s onwards, this model (like many others) has mainly concentrated on the most prototypical "narrow focus" clefts endowed with a "contrastive" effect, seeking to provide a detailed description of their syntactic (rather than strictly informational or pragmatic) properties, which will be briefly addressed below.

Cleft constructions are conceived as a specific utterance-type ("dispositif de la rection"), which necessarily makes use of the verb être (be) $)^{3}$ as in (1).

(1) c'est ta mère qui arrive

'it is your mother who is coming'

The notion of "utterance-type" refers to the way in which the various elements governed by a verb are arranged in the Verb-phrase, in order to highlight one of them, by giving it a distinctive focal value. It should be noted that our approach fundamentally aims at identifying the dependency relations holding between a verb and the various elements which it governs. As a dependency (rather than a constituency-based) model, the pronominal approach starts out from the syntactic observation that (1) illustrates a

\footnotetext{
${ }^{3}$ This implies that we would not adopt a designation like "il y a-clefts" (eg. il y a ta mère qui arrive, lit: there is your mother who is coming) since, in our view, such utterances are only loosely related to those illustrated in (1). See Conti (2017) for a discussion.
} 
dependency relation between a verb (arrive) and its Subject (ta mère): although uncontroversial, this analysis bears a major consequence for the description of the two remaining elements of the utterance, c'est (it is) et qui (who): such morphemes do not directly pertain to the syntactic construction (conceived as a set of dependency relations as stated above) but are to be seen as extraction marks that remain outside the realm of grammatical functions.

In such a view, c'est must be analyzed as a specific type of auxiliary verb which, as such, is totally unable to govern any element by itself, due to its "weakened" status (Blanche-Benveniste, 2001\& 2002): this is easily demonstrated by showing that this verb does not participate in the selection of the unit placed on its right. As an example, what makes (2) a fully grammatical utterance crucially relates to the fact that the verb parle (speak) has the ability to govern a PP introduced by $a$ (to), whereas the verb c'est plays no role whatsoever in the selection of that PP:

(2) c'est à Marie que je parle

'it is to Marie that I am speaking'

Conversely, the ungrammaticality of (3) results from the inability of the verb discute (discuss) to select a PP like à Marie (to Marie). Again, the verb être is not relevant in this respect.

(3) *c'est à Marie que je discute

*'it is to Marie that I am discussing'

Thus our approach quite radically differs from competing constituency-based models which suggest that cleft constructions be described as "une structure phrastique complexe composée d'une proposition principale à verbe copule et d'une proposition subordonnée de type relative" (Lambrecht, 2004, 21-22) ${ }^{4}$. Both grammatical units put forward by Lambrecht, "proposition principale" (main clause) and "proposition subordonnée" (subordinate clause), are highly problematic in our view, as far as cleft constructions are concerned:

Firstly, Lambrecht's proposal to consider the initial c'est $X$ sequence as the "main clause" of the utterance (which in turn implies that être (be) should be analyzed as some kind of "main verb") conflicts with the fact that, due to its weakened behavior mentioned above, être can hardly be granted such a central syntactic status. As a matter of fact, on dependential grounds, the actual "main verb" of a cleft is to be found inside the second sequence of the utterance, not the initial one.

Secondly, as has been convincingly argued by many researchers (inter alia Muller 2002, Blanche-Benveniste 2002, Gapany 2004), it seems very unlikely that the sequences starting with the que/qui element could be adequately analyzed as relative clauses: while such a suggestion could be viewed as somewhat justifiable when the extracted element is a Noun Phrase (as in (1), ta mère - your mother), we believe that it should be reconsidered as soon as the assumed "antecedent" belongs to other categories (such as adverbs, PPs or Conjunctional Phrases). For instance, qu'il viendra (that he will come), que je parle (that I am speaking) or que je suis triste (that I am feeling sad) do not meet the formal criteria of a "relative clause" in utterances like:

\footnotetext{
${ }^{4}$ Rialland et al. $(2002,598)$ similarly point out that clefts « differ from their non-cleft counterparts in that the information in the coda is expressed by a subordinate clause ».
} 
(4) c'est demain [qu'il viendra]

'it is tomorrow [that he will come]'

(5) c'est à Marie[que je parle]

'it is to Marie [that I am speaking]'

(6) c'est parce qu'il pleut [que je suis triste]

'it is because it rains [that I am feeling sad]'

As a matter of fact, as Lehmann $(1986,664)$ recalls, "A relative construction is a construction consisting of a nominal (or a common noun phrase, in the terms of categorial grammar) $[\ldots]$ and a subordinate clause interpreted as attributively modifying the nominal" (emphasis ours, FS and MNR).

Thus, as far as the analysis as a relative clause is concerned, a sequence like Marie [à qui je parle] (Marie [to whom I speak]) does meet the feature put forward by Lehman (namely, the nominal status of the 'antecedent' element Marie), whereas à Marie [que je parle] (to Marie [that I speak]), which is the actual version one would find in most clefts, does not.

As Blanche-Benveniste $(2002,109)$ puts it: «Il paraît assez vain de chercher à analyser les séquences c'est $\mathrm{N} q u$ - comme si $\mathrm{N}$ était le complément de c'est, suivi d'une relative $»^{5}$.

In short, (a) we will not refer to the overall structure of cleft constructions as a succession of a main clause and a subordinate relative clause; and (b) we will not describe the syntactic status of the extracted element in relation to c'est, but rather in relation to the verb by which it is governed.

As regards the dependency relation between the cleft element and the verb, let us point out that the former can typically be part of the valency of the verb, with the syntactic function of a Subject or an Object.

(7) c'est [monsieur Grégory] $]_{\text {subject }}$ qui arrive (spoken, CLEA)

'it is [mister Grégory] who is arriving'

(8) c'est [sur moi] $]_{\text {object }}$ que maman comptait (spoken, Corpaix)

'it is [on me] that mummy counted'

The cleft item can also remain outside valency relations, with the function of an Adjunct:

(9) Si l'on excepte la misérable bande de Gaza, c'est [au Liban] adjunct que la proportion des réfugiés vivant dans des camps est la plus forte.(written, Scappini 2006)

'If we leave aside the miserable Gaza strip, it is [in Lebanon] that the proportion of refugees living in camps is the highest.'

\subsection{Characterizing the governed elements of a Verb-Phrase}

Needless to say, a central aspect of grammatical description lies in our capacity to demonstrate that several elements are linked by dependency relations (rather than, say, mere discursive relations). In the specific case of constructions involving a verb, the

\footnotetext{
5 'It is of no help to attempt to analyze the c'est $N q u$ - sequences as if $N$ was governed by $c$ 'est, followed by a relative clause'.
} 
pronominal approach states that grammatical dependency regularly correlates with a set of paradigmatic features that will be illustrated below. (10), in which the NP les framboises (raspberries) functions as the Object of the verb déteste (hate), will serve as an example:

(10) il déteste les framboises

'he hates raspberries'

Feature1- Elements governed by a verb present a systematic equivalence between pronominal and lexical realizations of the syntactic slot ("proportionality" relations). In the case of (10), this can be verified by replacing the NP by a clitic pronoun (les):

(11) il les déteste

'he hates them'

Feature2- The interrogative or negative modality of the verb can spread on to its governed elements. Regarding negation, this feature makes it possible to develop a contrast between positive and negative polarities:

(12) il ne déteste pas les fraises mais les framboises

'he doesn't hate strawberries but raspberries'

(13) il déteste les framboises, pas les fraises

'he hates raspberries, not strawberries'

Feature3- Governed elements can be modified by a paradigmatic adverbial like surtout, seulement, uniquement (mostly, only)...

(14) il déteste seulement les framboises

'he only hates raspberries'

Feature4- Governed elements may occupy a focus position within various utterancetypes such as cleft, pseudo-cleft, or 'restrictive' utterance-types, among others:

(15) il déteste les framboises (« direct » utterance-type)

'he hates raspberries'

(16) c'est les framboises qu'il déteste (cleft)

'it is raspberries that he hates'

(17) ce qu'il déteste c'est les framboises (pseudo-cleft)

lit: 'what he hates it is raspberries'

(18) Il n'y a que les framboises qu'il déteste ('restrictive' utterance-type)

lit: 'there is only raspberries that he hates'

The set of features listed above illustrates the fact that the possibility for an element to be clefted is by no means an 'independent' property but is just one manifestation of a more fundamental syntactic fact: elements that can be governed by a verb own paradigmatic properties.

In our descriptive framework, the application of these criteria is essential since it enables us to distinguish between clearly dependent sequences (Object, Subject, Adjunct), that pertain to the strict domain of verbal syntax, from other configurations that do not possess any paradigmatic characteristic, and thus appear to be only loosely linked to the neighboring constructions, sharing with them mere 'associative', paratactic or discursive relations. 
Regarding the structures in c'est comme ça que (this is how ${ }^{7}$ ), we will attempt to show that a fundamental distinction can be made between:

a- those in which comme ça illustrates the paradigmatic features listed above, hence acquiring the value of a "prototypical" cleft (section 3.1.)

b- and those in which comme ça behaves in a different, non-paradigmatic, way: this type will be first designated in a vague manner as the "non-prototypical type". In section (3.2.) below, their status with respect to clefting will be discussed further.

\section{3. « C'EST COMME CA QUE »: TWO DIFFERENT TYPES}

\subsection{Prototypical clefts}

(19) and (20) below are instances of prototypical clefts. The governed status of the pronominal form comme ça will be demonstrated on the basis of the set of descriptive features introduced in the previous section.

(19) Sp1 : et vous parlez l'arabe marocain ou l'arabe standard

Sp2 : l'arabe marocain et standard les deux

Sp1 : les deux vous avez étudié donc à l'école ou

Sp2: non non non c'est à force de parler avec avec mes oncles mes mes tantes et j'ai un oncle qui est prof euh qui est professeur au Maroc des fois il m'apprend des petits mots des on discute on essaie de d'avoir des conversations et il m'écoute parler il me reprend il me corrige puis c'est comme ça que j'ai appris mais je sais pas l'écrire (spoken, CFPP 25)

'Sp1: and do you speak Moroccan Arabic or standard Arabic

Sp2: Moroccan Arabic and standard Arabic both of them

Sp1: both of them did you learn at school or

Sp2: no no no it was through practice with my uncles my aunts and an uncle of mine is a teacher err a teacher in Morocco sometimes he teaches me small words we discuss we try to have conversations and he listens to me speaking he corrects me then this is how I have learned but I don't know how to write it'

(20) donc euh comme tous les + hommes + de mon pays ben j'ai fait mon service militaire je n'avais pas de travail et + au cours du service militaire il y avait un concours pour euh devenir instituteur euh remplaçant c'est comme ça que on appelait ça à l'époque + donc j'ai passé ce concours + j'ai réussi ce concours (spoken, Corpaix $22)^{8}$

'so like every man in my country well I entered military service I had no occupation and during military service there was an examination to become a substitute school teacher this is how it was called at that time so I took the exam I passed the exam'

In both examples, comme ça is characterized the following paradigmatic features:

Feature1- Comme ça can be replaced by a lexical element:

\footnotetext{
${ }^{6}$ For the sake of simplicity, our mention of comme ça will also involve the comme cela versions (unless specified otherwise).

${ }^{7}$ In what follows, we will try to avoid the literal 'it is like this that' translation as often as possible.

${ }^{8}$ In the oral transcriptions, the $«+»$ symbol indicates the presence of a pause.
} 
(21) c'est en parlant arabe avec ma famille que j'ai appris

'it is by speaking Arabic with my family that I have learned'

(22) c'est instituteur remplaçant qu'on appelait ça à l'époque

'it is substitute school teacher that it was called at that time'

Feature2- Comme ça can be in contrast with a contextually given referent and create in this way a contrastive paradigm:

(23) ce n'est pas comme ça que j'ai appris mais en suivant des cours du soir

'it is not like this that I have learned but by taking evening classes'

(24) c'est comme ça que j'ai appris et pas en partant voyager au Maghreb

'it is like this that I have learned and not by travelling to the Maghreb'

(25) ce n'est pas comme ça qu'on appelait ça mais d'une autre manière

'it is not like this that it was called but in another way'

(26) c'est comme ça qu'on appelait ça et pas différemment

'it is like this that it was called and not differently'

Feature 3- Comme ça can be modified by a paradigmatic adverbial:

(27) c'est uniquement / surtout comme ça que j'ai appris

'it is only / mainly like this that I have learned'

(28) c'est uniquement comme ça qu'on appelait ça

'it is only like this that it was called'

Feature4- The construction can be used in other utterance-types ${ }^{9}$ :

(29) j'ai appris comme ça (« direct » utterance-type)

'I have learned like this'

(30) il n'y a que comme ça que j'ai appris (restrictive utterance-type)

lit: 'there is only like that I have learned'

(31) on appelait ça comme ça (« direct » utterance-type)

'it was called like this

(32) il n'y a que comme ça qu'on appelait ça (restrictive utterance-type)

lit: 'there is only like this that it was called'

As stated above, the paradigmatic properties show that, just as prototypical clefts, (19) and (20) have a contrastive interpretation. On syntactic grounds, the pronominal form comme ça must be conceived as governed by the verb, either as an Adjunct or as an Object:

(33) c'est [comme ça] Adj. que j'ai appris

(34) c'est [comme ça] obj. qu'on appelait ça à l'époque

Semantically, comme ça is unambiguously related to the expression of manner and could readily be questioned with the interrogative pronoun comment? (how?): comment l'as-tu appris? (how did you learn it?), comment est-ce qu'on appelait ça? (how was it called?). This amounts to saying that the syntactic and semantic status of comme ça originates in the verb's properties.

\footnotetext{
${ }^{9}$ Pseudo-clefts constructions are hardly compatible with elements related to the expression of manner.
} 
Let us now introduce two more examples which exhibit a quite different, and much less prototypical, behavior.

\subsection{A non-prototypical type}

We will now investigate a different type of c'est comme ça que structure which is well attested in our spoken corpora. In contrast with the prototypical type discussed above, this type cannot be described on the basis of the verb's dependency, which can be demonstrated by showing that the pronoun comme ça does not meet the criteria of paradigmatic structuring (3.2.1.). We will further suggest that such non-prototypical c'est comme ça que sequences can be seen as formulaic rigidly fixed expressions (3.2.2.). Lastly, we will take a closer look at the sequence placed after the que morpheme, showing that it significantly differs from that found in prototypical clefts (3.2.3.). Just in order to help the readers adequately understand the following instances (see the discussion in section 4), let us point out that c'est comme ça que is not semantically related to the expression of manner but serves to introduce a fact that is to be interpreted as a consequence of the set of facts previously mentioned by the speaker.

\subsubsection{Comme ça is not governed by a verb: review of some paradigmatic criteria}

The pronominal form comme ça of (35) and (36) does not meet the paradigmatic criteria which would attest its governed status. We chose to provide quite lengthy examples so that the discursive value of c'est comme ça que can be more easily grasped:

(35) ma thèse de de paléontologie est parue dans la revue scientifique + et ça m'a valu la première lettre de Jean Rostand me disant que ça l'avait beaucoup + intéressé et /qu'il, quil il me demandait il était déjà il dirigeait déjà la collection L'avenir de la Science chez Gallimard et alors il il me demandait si j'accepterais de faire un livre dans sa collection + alors euh j'étais toute un peu surprise de et alors j'ai demandé à Lucien Cuénot qui était mon patron je lui ai montré la lettre et puis je lui ai dit alors qu'est-ce que je vais répondre et il m'a dit oh mais faut accepter tout de suite + alors c'était j'hésitais un peu inquiète alors j'ai dit mais qu'est-ce que je m'en vais faire quel quel mais ce livre ressemble à ce livre sur le sujet alors il m'a dit oh ben on va réfléchir + alors bon et alors c'est comme ça que j'ai fait mon premier livre qui date de quarante huit "Les outils chez les êtres vivants" (spoken, Corpaix 7)

"my dissertation in paleontology was published in the scientific journal and that led me to receive a first letter from Jean Rostand in which he said how interested he was and he asked me he was already he was already the editor of the Future of Science series published by Gallimard and so he inquired whether I would accept to write a book in his series so I was quite surprised by and then I asked Lucien Cuénot who was my boss I showed him the letter and I asked him so what should I answer and he told me oh well you should give your agreement right away then it was I was hesitant and worried so I said well what could I do what what but that book is similar to that book on the subject then he told me well let's think about it then well and so this is how I wrote my first book which was published in forty eight "The tools used by human beings""

(36) petit à petit c'est l'ass- il y a une assimilation qui s'est faite après si tu regardes vu que c'est les Romains ils étaient essentiellement commerciaux aussi c'est c'était des guerriers mais avant tout c'était des commerçants donc euh c'est pour ça les voies 
fluviales les voies fluviales c'était principalement pour le commerce donc ils en remontant vu qu'à chaque fois c'est ils étaient Romains il y a aussi que l'administration elle tenait énormément les comptes et catera c'était par le c'était par le latin donc je pense que quand il y a le latin qui s'est foutu dans le commerce tout de suite après ça s'est ça a continué ça a continué c'est comme ça que petit à petit en cin-au bout de cinq siècles on s'est retrouvés avec le le latin qui était quasiment parlé par tout le monde (spoken, Tufs 8)

'progressively an assimilation took place since the Romans were essentially working in trade they were warriors too but above all they were merchants so err waterways waterways were mainly intended for trade so they since they always they were Romans it is a fact that the administration was very busy keeping accounts and so on this was made through Latin so I believe that as soon as Latin was used for trade immediately after that it went on and on this is how progressively five five centuries later we ended up with Latin being spoken by almost everyone'

Let us briefly review the paradigmatic properties of comme ça for both examples:

Feature1- Comme ça cannot easily be replaced by a lexical element:

Any attempt to provide a lexical equivalent to comme ça would require us to select only one of the elements introduced in the previous context, for instance:

(37) c'est grâce à l'invitation de Jean Rostand que j'ai fait mon premier livre

'it is thanks to Jean Rostand's invitation that I wrote my first book'

(38) c'est sur les conseils de Lucien Cuénot que j'ai fait mon premier livre

'it is on the advice of Lucien Cuénot that I wrote my first book'

(39) c'est par l'expansion du commerce romain qu'on s'est retrouvés avec le latin

'it is through the expansion of Roman trade that we ended up with Latin'

Although perfectly grammatical, such paraphrases do not seem appropriate, since, as will be further discussed in the following pages, one quite remarkable semantic and discursive feature of the non-prototypical c'est comme ça que type is precisely its capacity to "summarize" a whole series of previously mentioned facts, without referring to any specific one: for instance, in (35) and (36) above, c'est comme ça introduces the various facts which have led to the publication of the book (ex. 35), or to the widespread use of Latin (ex. 36). Consequently, the only way to give an acceptable lexical equivalent to comme ça would consist in choosing a very general resumptive expression such as:

(40) c'est par tout un concours de circonstances que j'ai fait mon premier livre

'it is as a result of a combination of circumstances that I wrote my first book'

(41) c'est à la suite de tous ces évènements qu'on s'est retrouvés avec le latin

'it is in the aftermath of all these events that we ended up with Latin'

Feature2- Comme ça cannot be realized as a contrastive paradigm:

(42) ?ce n'est pas comme ça que j'ai fait mon premier livre mais d'une autre manière

?'it is not like this that I wrote my first book but in another way'

(43) ? ce n'est pas comme ça que petit à petit au bout de cinq siècles on s'est retrouvés avec le latin qui était quasiment parlé par tout le monde mais d'une manière différente 
?'it is not like this that progressively five centuries later we ended up with Latin being spoken by almost everyone but in a different way'

Feature 3- Comme ça cannot be modified by a paradigmatic adverbial:

(44) ?c'est uniquement comme ça que j'ai fait mon premier livre

?'it is only like this that I wrote my first book'

(45) ? c'est seulement comme ça qu'on s'est retrouvés avec le latin...

?'it is only like this that we ended up with Latin...'

Feature 4- Other utterance-types do not provide fully equivalent versions:

(46) ? j'ai fait mon premier livre comme ça (« direct » utterance-type)

?'I wrote my first book like this'

(47) *il n'y a que comme ça que j'ai fait mon premier livre (restrictive utterance-type)

* 'there is only like this that I wrote my first book'

(48) ? on s'est retrouvés avec le latin (...) comme ça

? 'we ended up with Latin (...) like this'

(49) * il n'y a que comme ça que (...) on s'est retrouvés avec le latin

*'there is only like this that (...) we ended up with Latin'

As shown by the preceding syntactic manipulations, examples (35) and (36) do not possess any paradigmatic properties; this is why they do not convey the typical contrastive effect that characterizes prototypical clefts. As a consequence, the pronominal form comme ça must be considered as ungoverned by the verb. A notable consequence of its ungoverned status is that the pronominal form is not likely to saturate any syntactic function. In other words, an Adjunct related to the expression of manner could be introduced at the end of the Verb-phrase, in addition to the initial c'est comme ça, without conveying any notion of redundancy ${ }^{10}$ :

(50) il devait faire genre euh un mètre quarante il dépassait à peine le filet avec ses grands cheveux blonds et puis sa petite tête il était extra quoi et puis c'est comme ça que j'ai rencontré ce gars [en jouant au tennis] Adjunct $_{\text {(spoken, Ofrom 5) }}$

'He was like one meter forty high he was barely higher than the net with his long blonde hair and his little head he was just great you see so this is how I met this guy [playing tennis] $]_{\text {Adjunct' }}$

(51) Sans ses panneaux stellaires qui la lui fournissaient, le navire dut économiser l'énergie restante pour le fonctionnement du système de survie des bébés (les "Elus" dans le langage de l'ordinateur). C'est comme ça qu'il se précipitait sur Titan [tous feux éteints sans même s'en apercevoir $]_{\text {Adjunct }}$ (written litt, CERF 8)

'Deprived of its stellar panels that were supposed to supply it, the ship needed to save the remaining energy for the proper functioning of the babies'survival device (the "Elected ones" in the language of the computor). This is how it rushed towards Titan [with its lights off without even being aware of it] Adjunct $^{\prime}$

\subsubsection{C'est comme ça que: a formulaic expression}

\footnotetext{
${ }^{10}$ In the following two examples, prosodic and graphic cues suggest that comme ça is not linked to "playing tennis" or "with its lights off..." by a cataphoric relation.
} 
Beyond the issue of the syntactic status of comme ça, we will make a brief comment about the internal structure of the overall sequence c'est comme ça que as used in the "non-prototypical" type: it seems to be characterized by its rigidly fixed form, giving it a formulaic aspect. One notable fact is that adverbs of all kinds are unlikely to appear between c'est and que in our data. Such a limitation is not found in prototypical clefts, as illustrated by the following utterances:

(52) c'est justement comme ça que les patois vont disparaître (spoken, Corpaix 5)

'this is precisely how dialects are going to disappear'

(53) c'est vraiment comme ça que que je le ressens (spoken, Valibel 4)

'this is really how I feel it'

(54) C'est tout à fait comme ça que je la voulais! (written, litt, CERF 2)

'this is exactly how I wanted it !'

(55) C'est sûrement comme ça que la porte de ma chambre s'est ouverte tout à l'heure. (written, litt, CERF 3)

'this is surely how my bedroom's door opened a moment ago.'

The following example shows that even more lexical material can be inserted between c'est and que in prototypical clefts:

(56) c'est parfois comme ça en tout cas qu'on peut le faire (spoken, Ofrom, 7)

'it is sometimes like this anyway that you can do it'

Interestingly, Lahousse \& Lamiroy $(2017,169)$ make a similar comment about c'est ainsi que: "'Ainsi' ne peut être modifié par un autre adverbe que lorsqu'il a une fonction syntaxique en tant qu'adverbe de manière dans la clivée $»^{11}$.

\subsubsection{A few remarks about the sequence placed after que}

Our final comments in this section will be about some formal characteristics of the sequence starting after the que morpheme. There are a few striking differences between the two types, such as the following:

a- In the non-prototypical type, the Verb-phrase initiated after que can be in the negative; for instance:

(57) les missions des bibliothèques publiques + sont + au nombre de quatre essentiellem- essentiellement c'est la conservation en numéro un + l'information + le devoir d'information c'est comme ça qu'il n'est pas étonnant de + qu'on puisse trouver euh + depuis le plan de la ville + euh dans une bibliothèque mais aussi l'adresse de l'Agence Nationale Pour l'Emploi (spoken, CRFP 8)

' (...) this is how it is no surprise if we can find the city maps in a library but also the address of the National Employment Agency'

(58) c'est comme ça que enfin moi j'ai pas l'impression d'être aimée du tout tu vois (spoken, Tufs 19)

'this is how well I don't feel I am appreciated at all you see'

By contrast, the negative morpheme pas is systematically attached to the c'est auxiliary verb in prototypical clefts:

11 “"Ainsi' can be modified by another adverb only if it fulfills a syntactic function as an adverb of manner within the cleft". 
(59) [c'est pas] comme ça qu'on dit (spoken, Corpaix 4)

'[this is not] how you say it'

b- In the non-prototypical type, various kinds of (predominantly locative or temporal) adjuncts can be found between que and the S-V sequence:

(60) c'est comme ça que [petit à petit en cin-au bout de cinq siècles] on s'est retrouvés avec le le latin qui était quasiment parlé par tout le monde (spoken, Tufs 8)

'this is how [progressively five centuries later] we ended up with Latin being spoken by almost everyone'

(61) et c'est comme ça que euh [à côté de euh tout près de de de notre grande ville Dijon] + les moines + ont créé le Clos de Vougeot + avec une superbe cave (spoken, CRFP 5)

'this is how [near err close to our big city of Dijon] the monks created the Clos de Vougeot with a superb cellar'

(62) c'est comme ça que [au Portugal] tu as tous les joueurs brésiliens qui qui jouent voilà parce qu'ils sont considérés comme communautaires (spoken, Tufs 21)

'this is how [in Portugal] you have all the Brazilian players who who play well because they are considered as part of the same community'

The presence of an Adjunct right after the que morpheme seems to be very uncommon in prototypical clefts, as far as conversational speech is considered.

c- Rather than introducing a single clause, the non-prototypical type is likely to introduce a whole stretch of text, the length of the sequence being often very difficult to determine. Consider instances like the following :

(63) et c'est comme ça que le deuxième fils de Boumba Jogonda put semer la première graine et cette graine poussa elle profita elle grandit et elle grandit tant qu'un jour elle devint un arbre immense qui porta tous les fruits du monde (spoken, Oral French Narrative 3)

'and this is how Boumba Jogonda's second son could sow the first seed and that seed grew it expanded and it grew bigger and bigger so that one day it turned into a huge tree that bore all the fruit in the world'

(64) alors on s'est dit on va rentrer en Suisse romande et puis on va les scolariser on va faire notre vie en Suisse romande alors c'est comme ça qu'on est rentrés puis on a ouvert la pharmacie (spoken, Ofrom 15)

'then we said we will go back to the Suisse romande region and then we will send them to school we will spend our lives in Suisse romande so this is how we went back there and we opened a pharmacy'

This characteristic would be compatible with the analysis as a "prefab", which Hopper and Thompson $(2008,116)$ have developed regarding a variety of English and German expressions such as "what happens", "it's nice" or "wenn du luscht hasch"; the authors suggest that such forms "are not well-accounted for by assuming them to be first parts of biclausal constructions, but are best accounted for by seeing them as relatively openslot 'prefabs' which strongly project certain types of social actions, whose grammatical manifestation takes many different forms and may not be limited to one clause in length". 
This fact contrasts with prototypical clefts, which mainly seem to introduce well defined Verb-Constructions. Whenever several verbs are involved, the que morpheme tends to be repeated in front of each listed verbal sequence, as in:

(65) c'est parfois comme ça en tout cas qu'on peut le faire ou qu'on peut le ressentir (spoken, Ofrom 7)

'it is sometimes like this anyway that we can do it or that we can experience it'

\subsubsection{Synthesis: c'est comme ça que as a discourse connector}

What the previous remarks strongly suggest is that our non-prototypical type meets some characteristics of main clause phenomena: as has been previously observed, the sequence appearing after the que morpheme is compatible with a negative verb, or with the presence of preposed locative or temporal adjuncts, just like main clauses would be. But there is more to it: the third characteristic mentioned above suggests that it would be a reductionist view to see the c'est comme ça que sequence as necessarily linked to a subsequent "clause": rather, there seems to be no "fixed" extension of the portion of text introduced by the c'est comme ça que sequence.

In order to sum up the observations made in section 3, we wish to emphasize that in the non-prototypical type, the initial c'est comme ça que sequence and the subsequent one can be viewed as quite separate entities: on strictly syntactic grounds, it has been argued that the comme ça pronoun is not governed by the following verb, which makes it a grammatically "unrelated" element; the overall form of c'est comme ça que appears to be rigidly fixed, which makes it a formulaic sequence, with its own specific form; lastly, the form of the sequence placed after the que meets some characteristics of main clauses, even extending to whole stretches of discourse, which attests that its form owes nothing to the initial c'est comme ça que segment, from which it is largely independent.

This leads us to claim that the insertion of a c'est comme ça que segment into an utterance is not made through grammatical combining but is performed at a more discursive (in our terms, "macrosyntactic") level. Hence, in what follows, the c'est comme ça que segment of the "non-prototypical" type will be more precisely reanalyzed as a specific discourse connector ${ }^{12}$. Despite what appearances may suggest, we are not dealing with clefts anymore. In what follows, the somewhat vague terminological distinction between 'prototypical' vs. 'non-prototypical' types will be abandoned in favor of a clear-cut distinction between clefts and discourse connectors.

\subsection{Distribution of "c'est comme ça que" in the corpus}

The following table illustrates the distribution of both types in our corpora ${ }^{13}$ :

\begin{tabular}{|c|c|c|}
\hline c'est comme ça que & Number of occurrences & Percentage \\
\hline Cleft & 125 & $66,5 \%$ \\
\hline Discourse connector & 50 & $26,5 \%$ \\
\hline
\end{tabular}

\footnotetext{
${ }^{12}$ See Lahousse \& Lamiroy (2017) for a similar analysis concerning one type of "c'est ainsi que" sequences.

${ }^{13}$ Out of the 12 occurrences of c'est comme cela que found in our corpora, 6 consist in clefts, and 5 in discourse connectors (the remaining example could be analyzed in both ways).
} 


\begin{tabular}{|c|c|c|}
\hline Ambiguous between both types & 13 & $7 \%$ \\
\hline TOTAL & 188 & $100 \%$ \\
\hline
\end{tabular}

Table 3. Distribution of both types

As shown in Table 3, the contrastive comme ça-clefts appear to be much more frequent than their use as discourse connectors. Interestingly, this result contrasts with Lahousse \& Lamiroy's (2017) findings about c'est ainsi que constructions: in their survey, the non-prototypical structures slightly predominate (52\% of the cases).

Table 3 also indicates that in a minority of utterances (around 7\%), both interpretations are possible: in these cases, it proved impossible for us to decide whether we were dealing with a cleft or a discourse connector (see sub-section 4.2.1 below for some illustrations).

\section{4. « C'EST COMME CA QUE » AS A DISCOURSE CONNECTOR}

\subsection{Earlier studies}

The earlier studies devoted to the analysis of French adverbial / pronominal cleft-like structures have given rise to various descriptions as to their discursive value, as summarized in Table 4:

\begin{tabular}{|c|l|l|}
\hline \multirow{2}{*}{$\begin{array}{c}\text { c'est comme ça que } \\
\text { c'est pour ça que } \\
\text { c'est là que }\end{array}$} & Blanche-Benveniste 2006 & $\begin{array}{l}\text { 'Summary effect' (effet de } \\
\text { récapitulation) }\end{array}$ \\
\cline { 2 - 3 } & Scappini 2013 & 'Linking effect' (enchainement) \\
\cline { 2 - 3 } & Sabio \& Benzitoun 2013 & $\begin{array}{l}\text { 'Macrosyntactic structures } \\
\text { endowed with a discursive } \\
\text { effect' }\end{array}$ \\
\hline c'est ainsi que & Lahousse \& Lamiroy 2017 & $\begin{array}{l}\text { 'Cohesive function' } \\
\text { 'Connective value' }\end{array}$ \\
\hline c'est là que / où & Roubaud \& Sabio 2015 & $\begin{array}{l}\text { 'Discursive salience' } \\
\text { 'Discursive connection' }\end{array}$ \\
\hline
\end{tabular}

Table 4. The discursive value of some adverbial / pronominal cleft-like structures

We will now examine more precisely the discursive values of c'est comme ça que used as a discourse connector.

\subsection{Three discursive effects}

The main characteristic of the connective c'est comme ça que structures lies in the fact that they are not related to the expression of manner like they would be in clefts. Three slightly different discursive meanings can be distinguished, depending on whether c'est comme ça que introduces a consequence, a salient fact or an illustration. These are summarized in Table 5 and further discussed in sub-sections 4.2.1 to 4.2.3.

\begin{tabular}{|c|c|c|}
\hline Discursive effect & Broad equivalence & $\%$ \\
\hline
\end{tabular}




\begin{tabular}{|l|l|l|}
\hline \multicolumn{1}{|c|}{ of «c'est comme ça que » } & to other forms & \\
\hline $\begin{array}{l}\text { Introduces a consequence } \text { or the "logical } \\
\text { outcome" of the set of facts previously } \\
\text { mentioned }\end{array}$ & $\begin{array}{l}\text { en conséquence (as a consequence) } \\
\text { si bien que (approx. so that) } \\
\text { ce qui fait que (approx. with the result } \\
\text { that) }\end{array}$ & $\begin{array}{l}40 \text { occ. } \\
(80 \%)\end{array}$ \\
\hline $\begin{array}{l}\text { Introduces a salient fact } \text { which emerges } \\
\text { from the informational background }\end{array}$ & $\begin{array}{l}\text { c'est dans ces circonstances que (in } \\
\text { these circumstances) }\end{array}$ & $\begin{array}{l}8 \text { occ. } \\
(16 \%)\end{array}$ \\
\hline $\begin{array}{l}\text { Introduces an illustration connected to } \\
\text { the set of facts previously mentioned }\end{array}$ & par exemple (for instance) & 2 occ. $(4 \%)$ \\
\hline
\end{tabular}

Table 5. Connective «c'est comme ça que »: 3 discursive effects

\subsubsection{Introduction of a consequence}

In the data considered here, the expression of consequence is prevailing, which is consistent with Lahousse \& Lamiroy's (2017) findings about the connective use of c'est ainsi que. A noticeable feature is that such a discursive effect is mostly found in narrative texts. As an illustration, let us consider example (35) again, partially reproduced in (66):

(66) alors bon et alors c'est comme ça que j'ai fait mon premier livre qui date de quarante huit (spoken, Corpaix 7)

'then well and so this is how I wrote my first book which was published in forty eight'

In this passage, the speaker does not intent to describe the manner in which she wrote her first book; rather, she presents the writing of her book as a consequence of a series of earlier facts, as is summarized in Table $6^{14}$ :

\begin{tabular}{|l|l|}
\hline Set of facts & $\begin{array}{l}\text { - dissertation in paleontology published in a scientific } \\
\text { journal } \\
\text { - first letter from Jean Rostand expressing his interest } \\
\text { - proposal for the publishing of the dissertation } \\
\text { - request for advice from Lucien Cuénot } \\
\text { - period of uncertainty and worry }\end{array}$ \\
\hline \multicolumn{2}{|c|}{$c^{\prime}$ 'est comme ça que } \\
\hline $\begin{array}{l}\text { Introduction of a fact to be interpreted as a } \\
\text { consequence of the set of facts previously } \\
\text { mentioned }\end{array}$ & $\begin{array}{l}\text { j'ai fait mon premier livre qui date de quarante huit } \\
\text { 'I whote my first book which was published in forty }\end{array}$ \\
\hline
\end{tabular}

\section{Table 6. Overall discursive organization of ex (35)}

The meaning of c'est comme ça is thus quite comparable to other connective expressions like en conséquence / en conséquence de quoi (as a consequence), si bien que (so that) or ce qui fait que (with the result that).

The same discursive effect applies for (36), partially reproduced here as (67):

\footnotetext{
${ }^{14}$ An anonymous reviewer interestingly points out that even though comme ça does not indicate the way in which an action is performed (as it would in a cleft), it stills relates to the expression of manner, by expressing the way in which a whole series of facts leads to a specific consequence.
} 
(67) ça a continué ça a continué c'est comme ça que petit à petit en cin-au bout de cinq siècles on s'est retrouvés avec le le latin qui était quasiment parlé par tout le monde (spoken, Tufs 8)

'it went on and on this is how progressively five centuries later we ended up with Latin being spoken by almost everyone'

The speaker clearly introduces the emergence of Latin as a consequence of earlier historical facts.

As shown in Table 3 above, 13 occurrences (7\% of our data) are very difficult to classify as belonging to either the cleft type or the discursive type in a clear-cut way, since semantic and discursive clues leave open the possibility for both interpretations. The following two examples are some cases in point; the sequence c'est comme ça que could just as well be a cleft related to the expression of manner or a discourse connector introducing a consequence of a series of preceding facts:

(68) J'ai bien vu que le rouleau compresseur lui fonçait droit dessus. J'ai hurlé, mais le bruit des travaux a couvert mes cris. Alors, j'ai essayé de courir le prévenir, mais le béton avait déjà pris. Je n'ai rien pu faire... Quand le conducteur s'est rendu compte que le compresseur était rouge, il a immédiatement coupé le moteur et déclenché sa sirène. Il s'est retourné, a jeté un ceil sur sa trajectoire et est tombé dans les pommes dans sa cabine. Faut reconnaître que c'était pas beau à voir. C'est comme ça que j'ai perdu mon papa! Après, les gendarmes sont venus constater qu'il était bien mort. (written, CERF 5)

'I saw the road roller coming right into him. I screamed, but the noise from construction activities covered up my screams. Then I tried to alert him; but the concrete had already set. I couldn't do anything... As soon as the driver realized that the road roller was red, he immediately shut down the engine and started his alarm. He turned around, took a look at his trajectory and fainted in his cab. I must admit that it wasn't a pretty sight. This is how I lost my dad! Right after that, police officers came to confirm that he was dead.'

[Interpretation a] comme ça: I lost my dad like this / in this way (in an accident with a road roller)

[Interpretation b] c'est comme ça que: as a consequence / as a result, I lost my dad

(69) moi j'ai pris la décision d'aller à la salle de boxe et puis j'ai fait un entraînement deux entraînements et puis j'ai accroché et c'est comme ça que je suis devenu boxeur voilà donc ça ça a commencé à l'âge de douze ans (spoken, Tcof 2)

'I decided to go to the boxing gym and then I did one training session two training sessions and then I got into it and this is how I became a boxer so it started at the age of twelve'

[Interpretation a] comme ça: I became a boxer like this / in this way (through practice) [Interpretation b] c'est comme ça que: as a consequence / as a result, I became a boxer

The notion of consequence, although it is prevailing in our data, is not always present. The next sub-sections briefly discuss two other discursive effects, which are somewhat harder to characterize.

\subsubsection{Introduction of a salient fact}


In (70), c'est comme ça que does not introduce a consequence as such, but rather a "salient fact" that can be loosely related to the information provided in the preceding stretch of text:

(70) Spl: d' accord et euh vous vous savez pourquoi ils sont venus à Saint-Ouen pourquoi ils se sont installés

Sp2 : eh ben ils se sont mariés et puis mon grand-p- mon père ses parents étaient grainetiers à Pantin et il a voulu prendre un accompte grainetier et c'est comme ça qu'ils sont ils ont exploré un peu toute la région puis ça s'est trouvé que à Saint-Ouen il $y$ avait un coin à vendre (oral, CFPP 13)

'Sp1: OK and err do you know why they came to Saint-Ouen why they settled there Sp2: well they got married and my grand-f- my father his parents were seed merchants and he wished to become a seed merchant and this is how they started exploring the area and then by chance there was a place to be sold in Saint-Ouen'

\subsubsection{Introduction of an illustration}

Lahousse and Lamiroy (2017) show that, in a significant number of cases, c'est ainsi que can be used in order to connect an overall principle to a specific illustration of what has been previously mentioned. By contrast, our data contains very few utterances in which c'est comme ça que seems to convey such an "illustrative" value. The following example, however, can be considered relevantly similar to the examples in Lahousse and Lamiroy (2017):

(71) et les moines de Cluny par exemple avaient des vignes jusqu'à proximité de Dijon + et on avait aussi dans notre région + l'abbaye de Cîteaux + les moines de Cîteaux + $q u i+$ se sont beaucoup beaucoup $=t=a-$ attachés + là aussi au vin + pourquoi + parce que le vin rouge c'est une symbolique très forte dans l'église chrétienne + le vin rouge + c'est le sang du Christ + or notre Pinot Noir notre cépage qui donne de bons arômes $+c^{\prime}$ est un raisin rouge à jus blanc + voyez quand on presse comme ça on prend une grappe + on la serre tout de suite on la presse + le jus qui coule c'est un vin blanc c'est comme ça que le champagne par exemple est fait avec du Pinot Noir + mais il est parfaitement blanc (oral, CRFP 4)

'and the monks of Cluny for instance used to own vineyards near Dijon + and we had in our area as well + the Cîteaux abbey + the monks of Cîteaux who were very much involved + in winemaking + why + because red wine is a strong symbol for Christian church + red wine is the blood of Christ + yet our Pinot Noir our grape variety gives good flavor + it is a red grape with white juice + you see when you squeeze it like this you take a bunch + you press it right away + the juice which flows is a white wine this is how champagne for instance is made out of Pinot noir + but it is perfectly white'

The fact that Champagne is made out of Pinot noir and that it is a white wine can hardly be regarded as "consequences" of the set of facts given in the previous context. Rather, this may be interpreted as a prime example of the expertise of the Burgundy area in the field of winemaking.

\section{CONCLUDING REMARKS}

As a final remark, we wish to point out that the difference between clefting and discursive connection which has been discussed here can be further interpreted through 
the distinction between microsyntactic and macrosyntactic structuring (BlancheBenveniste et al. 1990, Sabio 2018). That double dimension of grammatical organization can be briefly summarized as follows: the microsyntactic level accounts for dependency relations between a syntactic head and its various governed elements (Subject, Objects and Adjuncts); whereas the macrosyntactic level mainly concerns the relationships that go beyond strict government relations. It appears that c'est comme ça que sequences must be described at both levels, according to their grammatical status:

1-When used as clefts, c'est comme ça que sequences have both a microsyntactic and a macrosyntactic dimension: part of their structure pertains to microsyntax since, as we have suggested, the cleft pronoun is governed by a verb (as an Object or an Adjunct).

But they also have to be dealt with at the macrosyntactic level, since clefts regularly imply some kind of discursive and prosodic segmentation between two successive elements, namely the Nucleus (Noyau) of the utterance and the post-Nucleus (postNoyau). For instance, the example in (19) above can receive the following analysis:

Microsyntax : c'est [comme ça] Adjunct que j'ai appris lit:' 'it is [like this] $]_{\text {Adjunct }}$ that I have learned'

Macrosyntax : [c'est comme ça $]_{\text {Nucleus }}$ [que j'ai appris] PostNucleus lit: '[it is like this $]_{\text {Nucleus }}$ [that I have learned] $]_{\text {PostNucleus }}$

2-By contrast, when analyzed as a discourse connector, comme ça loses all connection with the microsyntactic component of grammar, because of its ungoverned (we might say its "desyntactized") status ${ }^{15}$ : it appears to be related to the following stretch of text on purely discursive grounds. Hence, it exclusively contributes to the macrosyntactic component of grammatical cohesion. For instance, (36) could be segmented in the following way:

\begin{tabular}{|l|l|l|l|}
\hline DISCURSIVE CONNECTOR & PRENUCLEUS & \multicolumn{1}{|c|}{ PRENUCLEUS } & \multicolumn{1}{|c|}{ NUCLEUS } \\
\hline c'est comme ça que & petit à petit & au bout de 5 siècles & on s'est retrouvé avec le latin \\
\hline 'this is how & progressively & 5 centuries later & we ended up with Latin' \\
\hline
\end{tabular}

Table 7. Macrosyntactic segmentation of ex (36)

The double status of comme ça which has been suggested here is after all not so surprising: it has been demonstrated (Debaisieux dir. 2013) that many morphemes which are commonly regarded as having a fundamentally microsyntactic status ${ }^{16}$ may also be used by speakers as a macrosyntactic tool; in this respect, the behavior of c'est comme ça que sequences is yet another illustration of the pervasiveness of the microvs. macrosyntax distinction in discourse elaboration.

15. Lahouse \& Lamiroy (2017) suggest that the "connective" use of c'est ainsi que should be described as a grammaticalized structure: although their demonstration is perfectly convincing, we are somewhat reluctant to adopt the word "grammaticalization", which might imply (at least in its literal reading) that the use of c'est comme ça que as a discourse connector could be viewed as more "grammatical" than its use as a genuine cleft, which is obviously not the case, as we have tried to show : in this respect, we would rather conceive connective c'est comme ça que sequences as "desyntactized".

${ }^{16}$ Such is the case for subordinate conjunctions like parce que (because), alors que (whereas), si (if)... 


\section{References}

Biber, Douglas and Susan Conrad. 2009. Register, Genre and Style. Cambridge University Press: Cambridge.

Blanche-Benveniste, Claire. 2001. "Auxiliaires et degrés de 'verbalité'. "Syntaxe et sémantique 3:75-98.

Blanche-Benveniste, Claire. 2002. "Macro-syntaxe et micro-syntaxe : les dispositifs de la rection verbale." In Macro-syntaxe et macro-sémantique, ed. by Hanne Leth Andersen and Henning Nølke, 95-115. Berne: Peter Lang.

Blanche-Benveniste, Claire. 2006. "Les clivées françaises de type : C'est comme ça que, C'est pour ça que, C'est là que tout a commencé.” Moderna språk 100: 273-287.

Blanche-Benveniste, Claire, José Deulofeu, Jean Stéfanini and Karel van den Eynde.1984. L'Approche pronominale et son application au français. Paris: SELAF.

Blanche-Benveniste, Claire, Mireille Bilger, Christine Rouget, Karel van den Eynde and Piet Mertens. 1990. Le français parlé. Études grammaticales. Paris: Éditions du CNRS.

Conti, Virginie. 2017. Autour du clivage et de phénomènes apparentés en français contemporain : le cas des structures en j'ai X qui V. Doctoral Dissertation, Université de Neuchâtel.

Debaisieux, Jeanne-Marie (dir.). 2013. Analyses linguistiques sur corpus. Subordination et insubordination en français contemporain. Paris: Lavoisier/Hermes Science.

Deulofeu, José. 1991. "La notion de dépendance syntaxique dans l'approche pronominale." L'information grammaticale 50: 19-24.

Doetjes, Jenny, Georges Rebuschi and Annie Rialland. 2003. "Cleft Sentences."In Handbook of French semantics, ed. by Francis Corblin and Henriëtte de Swart, 529552. Stanford: CSLI Publications.

Gapany, Joël. 2004. Formes et fonctions des relatives en français. Étude syntaxique et sémantique. Berne: Peter Lang.

Hopper, Paul and Sandra A. Thompson. 2008. "Projectability and Clause Combining in Interaction." In Crosslinguistic Studies of Clause Combining: The Multifunctionality of Conjunctions, ed. by Ritva Laury, 99-124. Amsterdam/Philadelphia: John Benjamins.

Lambrecht, Knud. 2004. "Un système pour l'analyse de la structure informationnelle des phrases. L'exemple des constructions clivées." In Structure informationnelle et particules énonciatives. Essai de typologie, ed. by Jocelyne Fernandez-Vest and Shirley Carter-Thomas, 21-62. Paris: L'Harmattan.

Lahousse, Karen and Béatrice Lamiroy. 2017. “C'est ainsi que' : grammaticalisation ou lexicalisation ou les deux à la fois ?"Journal of French Language Studies27 (2): 161185.

Lehmann, Christian. 1986. "On the Typology of Relative Clauses.'Linguistics 24: 663680 .

Muller, Claude. 2002. "Clivées, coréférence et relativation." In Traits d'union, ed. by Georges Kleiber and Nicole Le Querler, 17-32. Caen: Presses Universitaires de Caen. 
Rialland, Annie, Jenny Doetjes and Georges Rebuschi. 2002. "What is Focused in C'est XP qui/que Cleft Sentences in French?" Speech Prosody 2002, Proceedings of the First International Conference on Prosody, 595-598.

Roubaud, Marie-Noëlle and Frédéric Sabio. 2015. "Les clivées en 'c'est là où' et 'c'est là que' : structure et usages en français moderne.”Repères-DoRiF6 [online].

Sabio, Frédéric. 2018. "On the Syntax of Spoken French: Government-Units and Utterance-Units." Revue Romane 53:1, special issue on models of discourse units in romance languages, ed. By Vahram Atayan, Margarita Borreguero Zuloaga and Sybille Grosse. 6-29.

Sabio, Frédéric and Christophe Benzitoun. 2013. "Sur les relations entre syntaxe et discours : dispositifs de la rection et dispositifs macrosyntaxiques." Studia Universitatis Babes-Bolyai Philologia 58 ( 4) : 97-110.

Scappini, Sophie. 2006. Étude du dispositif d'extraction en «c'est...qu-», différenciation entre une relative et un dispositif d'extraction en "c'est-...qu-». Doctoral Dissertation, Université de Provence.

Scappini, Sophie. 2013. "Un sous-type de la construction clivée en 'c'est qu-' : la structure d'enchaînement 'et c'est pour ça que...' et d'autres exemples." Studia Universitatis Babes-Bolyai Philologia 58 (4): 81-95.

Van den Eynde, Karel and Piet Mertens. 2003. "La valence: 1'approche pronominale et son application au lexique verbal." Journal of French language studies 13: 63-104. 